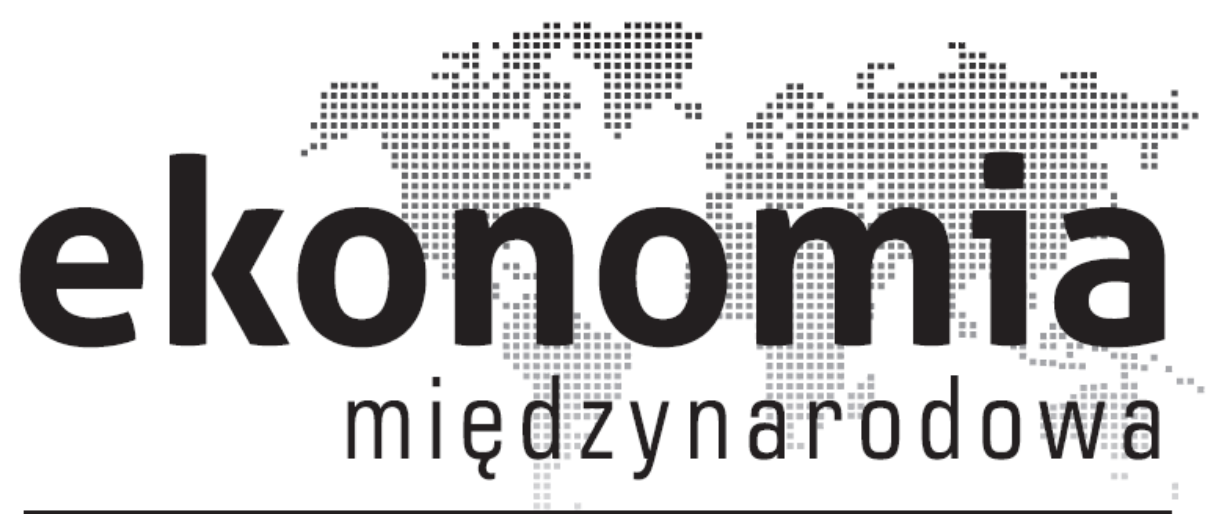

Ekonomia Międzynarodowa

$\mathrm{Nr} 13$ (2016)

Wydawca: Uniwersytet Łódzki

(Publisher: University of Lodz)

www.ekonomia-m.pl

ISSN: 2082-4440 - wydanie papierowe (paper edition)

ISSN: 2300-6005 - wydanie elektroniczne (electronic edition)

Wersja elektroniczna czasopisma jest wersją referencyjną

(Electronic edition is the reference version of the journal)
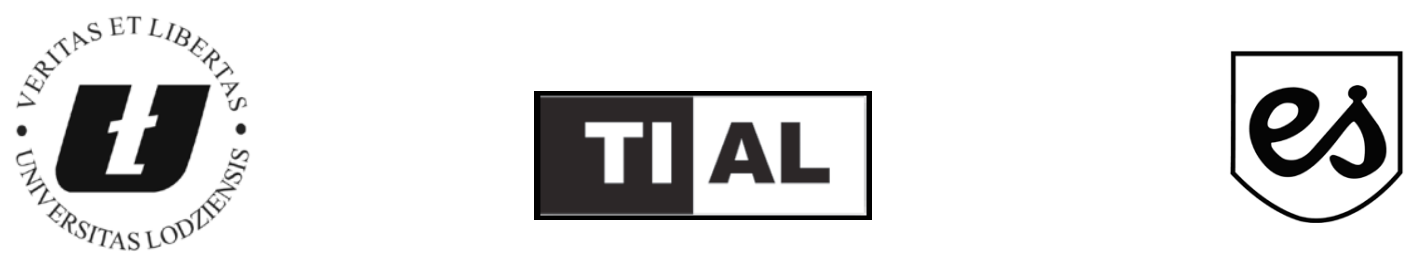


\section{Foreign trade and the theory of optimum currency areas. Implications for Poland}

Iwona Maciejczyk-Bujnowicz*

\section{Introduction}

The literature provides an abundance of studies on the benefits and losses connected with giving up a national currency to adopt a new one, common for a larger territory. Thus, the questions arise: when and on what conditions could the adotion of a common currency by two countries of two different currencies be a beneficial solution? According to the OCA (Optimum Currency Area) theory , an optimum solution should guarantee the attainment of fundamental goals of economic policy, i.e. full employment, external balance and the stability of prices. Substantive debate on the benefits and losses relating to the currency union and the adoption of a common currency by individual economies is still going on. For us it will not be the focal point of this Chapter. Our objective is to present selected data on Polish trade compared against data on trade between euro area member states, or more broadly the European Union, and third countries in the light of selected theoretical aspects of the traditional role of optimum currency areas and a new theoretical approach as well as selected results of empirical studies.

The paper's aim is the analysis of selected studies on the subject in question and the analysis of statistical data reflecting trade between Poland and the euro area, on the one hand, and Poland and the EU member states from outside of the euro area, on the other hand, in the period 2000-2010. Considerations are based on theoretical achievements of the optimum currency area theory. Due to restrictive space requirements, we will focus on the analysis of the endogenous approach to the optimum currency area criterion and trade in theoretical context. Based on that, we will try to make an assessment and answer the question whether Poland's

\footnotetext{
* Iwona Maciejczyk-Bujnowicz - PhD, University of Lodz, Faculty of Economics and Sociology, Department of International Economic Relations.
} 
integration with the EU has largely contributed to an increase in trade between Poland and euro area member states from the viewpoint of the objective of the paper.

\section{Optimum currency area theory - evolution of the theoretical concept}

Studies devoted to the creation of a currency union, accession of new countries to it and the consequences of being inside the union are based on the achievements of the optimum currency area theory (OCA). OCA theory defines criteria (conditions) which must be complied with before two countries adopt a common currency (a pegged/fixed exchange rate). In the traditional approach defined by Mundell (1961), McKinnon (1963), and Kenen (1969), the adoption of a common currency is optimum for countries which have adequate adjustment mechanisms that can be quickly activated in case of asymmetric shocks between them. It is worth stressing that the models by Mundell, McKinnon and Kenen are based on the Keynesian assumptions of price rigidity. A currency area is considered optimum when there is mobility of production factors. Benefits of a monetary union increase with the enhancement of economic integration among countries-members of the union with a potentially possible reduction of associated costs. In accordance with traditional OCA theory, one of the fundamental issues to be considered by a country joining a single currency area is the existence of a similar, although diversified, structure of demand, production, and exports of the country in relation to the structures of the members of the area (Bilski, 2006). It allows the so called asymmetric shocks to be minimised. In contrast to symmetric shocks, the consequences of which are equally distributed across all the members of the area, asymmetric shocks hit, to a greater or lesser extent, a country or a group of countries.

The problem of optimum production structure within OCA theory was mentioned for the first time by Kenen (1969), who drew attention to the relation between the degree of product diversification in domestic production and the scale of the impact of negative external shocks on production, investment and employment. In this case, the author stresses that deeper diversification of the export product mix means a greater probability that shocks in demands for specific groups of products will level each other out, which means higher resistance of the economy to fluctuations in the aggregate demand for exports. Based on his considerations, the author stresses that strongly diversified export production makes the economy less susceptible to both internal and external asymmetric shocks. In literature the synchronisation of macroeconomic shocks is referred to as the "meta-criterion" for the establishment of an OCA (Kenen, 1969). It may mean e.g. that the higher the similarity of economic structures, the more synchronized business cycles of interconnected economies. This, in turn, inclines towards a common currency policy, which transmits monetary impulses relatively uniformly. We need to stress 
that in the case of both symmetric and asymmetric shocks, we may speak of demand or supply shocks. Demand asymmetric shocks are important for the assessment of benefits and costs connected with joining the euro area. The assumption is that similar consumption patterns and production or export structures in individual countries of the monetary union will not provoke significant differences in the consequences as the shock hits all the countries uniformly (Mongelli, 2002). The mobility of production factors, price and wage flexibility and fiscal and financial integration help the economy absorb shocks vis-à-vis other members of the monetary union (symmetry).

If business cycles of the countries in a monetary union are similar, the risk of asymmetric shocks is relatively low (flexibility). When economies are strongly diversified in respect of the above elements, a rapid drop in demand for a particular product, whose share in the overall output of a country is relatively high, differently impacts individual sectors of the member states of the common area. Hence, when considering the benefits and costs of joining a group of countries, which use a common currency, the theoretical assumption of a similar, convergent business cycle in the countries in the monetary union is important. The more convergent the economic situation, demand and supply structures of the countries, the more uniform the impact of a rapid external impulse of a change in external demand or supply across individual economies. Otherwise, the deployment of instruments of a single currency policy in the area will destabilise the economies causing increased inflation in some of them and decreased employment in others. In the opinion of Wójcik (2008), nominal and real convergence ${ }^{1}$ criteria in the catching-up process are of key importance. For example, Gros (2001) claims that the degree of real convergence should not be too much of a problem for countries joining the euro area to quickly integrate in monetary terms. The argument here is that, in essence, real convergence is supply-based and that is why it should not adversely affect the economic condition of those countries which joined the EU on 1 May 2004 after they enter the euro area. The opponents argue that adhesion to the euro should be preceded by the attainment of real convergence or, at least, an appropriate level thereof. Their arguments are based on the conclusion that the gap these countries should close in relation to other EU member states is dramatically wide compared to those which joined the euro area earlier. Against this background there is a highly interesting and heated theoretical discussion on the adequacy of nominal criteria from Maastricht for the structure and development stage of economies of the countries which joined the EU in 2004.

As we already indicated at the beginning of this paper, attention shall focus on one of the aspects of the OCA theory and the endogenous approach, i.e. on the analysis of the openness of the economy in respect of trade flows and mutual trade

\footnotetext{
${ }^{1}$ In a broader sense, , real convergence is about the convergence of structural characteristics of an economy; in a narrower sense, it is identified with the growth of the economy measured with the GDP per capita.
} 
relations among countries of the common currency area. According to McKinnon (1963), a high degree of openness of candidate economies is the prerequisite for creating an OCA (Bilski, 2006). Thus, the area can be created by countries with a large share of international trade in their GDP. The more open an economy (measured by the relation of exports and imports flows to the GDP), the higher the importance of foreign exchange rate for domestic prices. Economic openness is measured with the relation of tradable goods to goods traded domestically, which are referred to as non-tradable. A high share of tradable goods in the consumer goods of a country means a higher dependence of domestic prices on world market prices in the analysed currency area. There is a general conviction that in a country of a high degree of openness, the price effect of devaluation will be relatively higher than in a less open economy. At the same time, in a more open economy, the quantitative effect, i.e. the impact of devaluation on the competitiveness of national enterprises and an increase in output will be more limited than in a country which is relatively closed.

Literature studies indicate that one of the benefits of joining the euro area is trade intensification. It is the effect of the elimination of transaction costs and of the risk connected with exchange rate fluctuations. That is why one of the assumptions for the creation of a single currency area is an enhanced intensity of trade as a result of easier, cheaper and less risky trade among its members. Further, increased trade is to favour production specialisation and brings benefits such as the so called economies of large-scale production, which translate into higher productivity and more investment. We must add that the validity of the last assumption is analysed particularly intensely in the literature.

Contrary to the so called old OCA theory, the new approach to OCA (Mongelli, 2002) stresses the benefits of establishing a monetary union and the clearly decreasing importance of costs. Economists agree that the primary assumptions of the theory put too much stress on the scale of costs and they underappreciated the potential opportunities resulting from currency unification. The endogenous effect of integration-related processes is a consequence of exchange rate risk elimination and the abolition of all borders (together with borders delineated by the use of a national currency). It contributes to the shortening of distances, reducing transaction costs (also the cost of currency exchange) and the cost of insurance against exchange rate risk. Also, the costs of gathering information are reduced. This is due to the fact (Lutkowski, 2004) that currency is more useful when its area of application is bigger (the network effect). A common currency helps reduce or even remove these barriers, the so called border effect or home bias, by which it may significantly impact the size and directions of international trade (Tchorek, 2009).

Figure 1 presents the traditional approach, which is the starting point for further considerations, both theoretical and based on earlier obtained empirical results. 
Figure 1. Traditional approach to costs and benefits of a currency union resulting from the openness of the economy in GDP (\%)

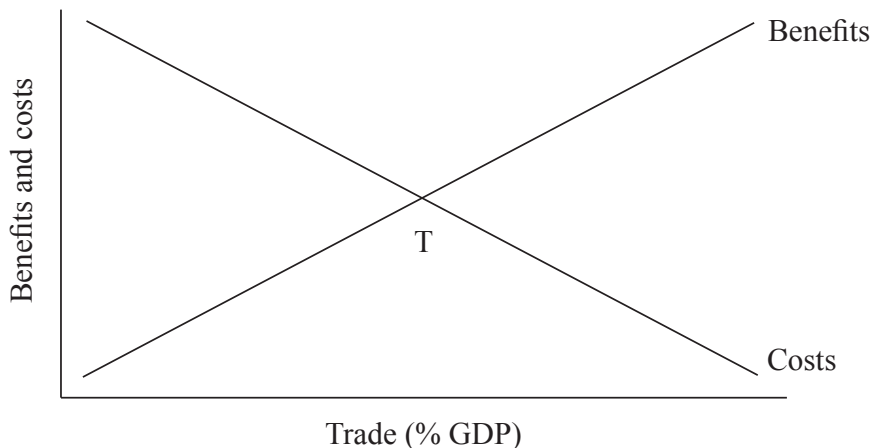

Source: own study based on De Grauwe 1994, De Grauwe 2003, p. 89.

In the traditional approach, the benefits curve goes upwards while the costs curve goes downward with the advancement of the integration among monetary union member states measured by the share of trade in the GDP (\%). We must stress that in our cost-benefit analysis, we take account of one of the elements, i.e. the degree of openness of economies measured with the share of trade (exports plus imports) in the GDP. On Figure 1, the intersection point of the two curves marked with $\boldsymbol{T}$ determines the critical degree of openness, which makes it worthwhile for a country to join a monetary union (De Grauwe, 2003). Left from this point, the benefits of having a country's own currency are higher than doing away with it, while right of the point it is more beneficial for a country to join a common currency area. The above approach to benefits and costs connected with changes in trade is reflected in the two main streams of economic theory: monetarism and Keynesianism. Figure 2 presents both approaches.

Figure 2. Costs and benefits connected with fluctuations in trade of the members of a currency union-monetarist and Keynesian approach

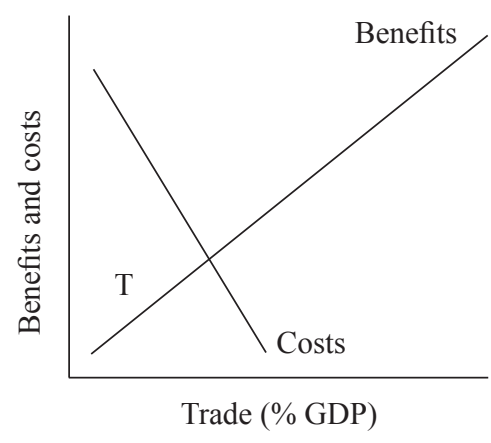

a. monetarist approach

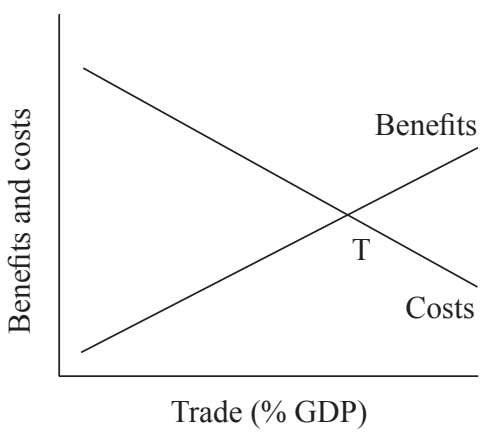

b. Keynesian approach

Source: De Grauwe 2003, p. 90. 
Monetarists believe the costs curve is very close to the origin of the $\mathrm{x}, \mathrm{y}$-coordinates system and its slope is high, meaning changes in the exchange rate are ineffective when it comes to restoring the balance. The argument is that, in the long-run, the exchange rate is not an effective instrument of improving economic competitiveness and it can be used only in the short-term as an adjustment tool. For example, nominal depreciation of a country's currency improves the competitiveness of its exports but relative increase in prices of imports intensifies inflationary tendencies, which leads to real appreciation of the currency and reduced competitiveness of the country. Monetarists argue that, under such circumstances, the benefits from joining a monetary union will materialise very quickly and it is more profitable for countries to join a monetary union than to remain outside of it, even when economic convergence criteria differ for them.

This view was adopted in the European Commission report (1990). According to the Commission, in the case of symmetric shocks, the exchange rate is not an effective instrument to stabilise the economy. It goes on to say that the symmetry of disturbances largely depends on trade integration. Moreover, the Commission adds that progressing economic integration in the European Union reduces the probability of asymmetric shocks due to the diversified production structure in countries-members of the grouping (contrary to the Keynesian position). In opposition to the stance of the European Commission, Krugman (1993) claims that increasing integration leads to deeper specialisation among members of the monetary union, decreasing business cycle correlations and, as a result, higher susceptibility to asymmetric shocks.

Keynesian economists stress that, due to price and wage rigidity in the economy and the lack of labour mobility, the exchange rate may become an effective balance restoring instrument. It means that currency integration may be preceded with trade integration. The cost curve is located relatively further away from the origin of the $\mathrm{x}, \mathrm{y}$-coordinates system and the benefits from joining a monetary union appear relatively late. De Grauwe (2003) states that in such a case, big countries should be divided into smaller currency zones.

Based on the above, we may conclude that in accordance with the view of Keynesian economists, countries of a relatively high share of trade in the GDP will benefit more from joining a monetary union compared to countries with a low openness index. On the other hand, however, monetarists stress that even countries with a relatively low share of trade in the GDP may experience lasting benefits exceeding costs. Unfortunately, such an assumption would be very risky, as taking account of other elements in the analysis could lead to completely opposite conclusions. Differences in the degree of openness to trade among various countries are not the only criterion for membership in a monetary union.

The results of studies by De Grauwe and Schnabl (2004) demonstrate that exchange rate stability in the CEE countries reduced inflation and instigated economic growth. According to the authors, this positive impact of the stable exchan- 
ge rate on economic growth, comes from, among others, a stable exchange rate of a country's currency vis-à-vis the euro, leading to increased trade between partners. It is predicted that the process will also continue after the country in question joins the euro area and, most probably, it will result from the endogeneity of OCA theory (Frankel, Rose, 2002). It means the countries, which in the ex ante period do not meet the optimality criteria in accordance with the traditional OCA theory, will be able to meet them ex post, after they have joined the monetary area. This view is additionally confirmed by studies conducted by Micco et al. (2003), where it was noted that membership of new countries in the monetary union increases their trade with old members of the area to an extent greater than it would have been the case if they had stayed outside of the common currency area. The analysis showed that within four years of adopting the euro, trade among the member states increased on average by $4-16 \%$. The authors also add that increased trade did not limit trade with countries from outside the area. A similar opinion on the impact of a common currency on trade and growth was presented by Lutkowski (2009). He explains the phenomenon with "endogenous understanding of optimum currency area criteria". Following representatives of this school of thought, he states that a monetary union, established even when OCA criteria are not fully met in the traditional interpretation of the idea (Mundell (1961), McKinnon (1963), Kenen (1969)), to a certain extent spontaneously initiates processes leading to catching up (...) and meeting the criteria after joining the union (...) and it itself provides the basis, which enables and justifies its existence and economic efficiency (Lutkowski 2009).

\section{Endogeneity of the optimum currency area criteria and synchronisation of business cycles of countries within the monetary union}

Assuming that the costs of monetary currency decrease with the increasing openness of the economy, and that the basic cost of a monetary union is the elimination of the exchange rate as an instrument of economic policy, according to the new theoretical approach, a monetary union may be an optimum area even when the adjustment mechanisms do not work in the case of asymmetric shocks. Specific studies analyse the scope of susceptibility of a country to asymmetric shocks. By the end of the 1990s, Frankel and Rose $(1997,1998)$ had already stressed that the type of integration-induced trade we are dealing with and the type of shock are very important. If a common currency contributes to intensified trade among the countries of the area, which indirectly synchronises business cycles, a common monetary policy in the monetary union makes it more balanced. Studies by Bussiere (2008) demonstrate that within a decade, i.e. in the years 1993-2003 
countries of Central and Eastern Europe experienced very strong trade integration with the euro area members, which implied two things. Firstly, for the euro area countries, the share of the Central and Eastern European countries in their trade doubled in the period in question and these countries as a group became the third biggest trade partner of the euro area members after the UK and the United States. Secondly, for Central and Eastern European countries, the euro area became the most important trade partner. Rose (2008), based on existing studies and the literature, conducted a meta-analysis ${ }^{2}$ of the effect of common currencies on international trade using a gravity model. He examined fixed effects and random effects for meta-estimates common to the entire thematic field. Considering the data for the euro area, based on 26 studies, he noted that the members of the area had already seen trade a rise of at least $8 \%$ (fixed effects) to even $23 \%$ (random effects). The author makes a reservation that the euro area is a relatively young organism and studies are limited by the time series available for a relatively short period.

For example, Baldwin (2006) estimated that the use of the euro in trade within the euro area probably did boost intra-Eurozone trade by on average ca. 5-10\% but he also says that these estimates may change in time when the monetary union has lasted longer and new years of data emerge. In the literature on trade we can find two effects of the establishing and functioning of the euro area (Rose, 2008). These are: direct and indirect effects. The first one relates to the increase in trade as a consequence of linking a group of countries with a common currency, while the indirect impact of the area is reflected in a deeper synchronisation of business cycles of the members of a monetary area.

In the above mentioned study, Rose (2008) reviewed the literature and analyses of the effect of trade between countries on the synchronisation of business cycles and, based on that, he concluded that there is a positive statistic and substantive justification. Making estimates based on the results of twenty studies by different authors, he noted that a 1-per cent increase in trade between countries increases by 0.02 the correlation coefficient, which measures business cycle synchronisation. In conclusion, the author states that the existence of the EMU increased trade and the synchronisation of business cycles among the members of the area. Thus, he justifies why there is no need for each and every individual member of the area to pursue its own separate national monetary policy. In his study, Rose (2008) also stresses that one of the benefits of establishing a common currency area is its trade promoting effect. The author draws special attention to the simultaneous impact of these two elements. His thesis is that, in practice, a currency union that does not look like an optimum currency area ex ante, may become one ex post. This condition is met when trade between countries increases enough to make the course and fluctuations of the business cycle comparable and, as a result, monetary policy in the monetary union will be uniform for all its members.

\footnotetext{
${ }^{2}$ Meta-analysis is a collection of quantifiable methods used to evaluate empirical studies in a given thematic field coming from various publications.
} 
According to traditional OCA theory, the loss of monetary independence when joining the euro area may turn out to be costly when business cycles of the new members of the area are not yet aligned with those of its major countries. Some authors claim (Flandreau, Maurel, 2005) that candidates to become new Eurozone members should join it as fast as possible independently of the harmonisation of their business cycles with the cycles of the Eurozone economies. Fast joining the euro area is especially stressed by the new EU member states. However, the proponents of this recommendation, Babetskii (2005) and Frankel (2004), base their view on the endogeneity of the optimum currency area criteria considering only the trade effects of integration (increased trade between countries). In the literature there is no consensus that increasing trade between countries leads to greater synchronisation of business cycles of their economies.

Krugman (1993) points out that, as countries become more integrated, they increasingly specialise in certain fields of production. Thus, Krugman draws our attention to the fact that potential industry-specific asymmetric shocks will become country-specific shocks for the members of the currency union. The results of studies by Frankel and Rose $(1997,1998)$ question Krugman's thesis. They explicitly stress that intra-industry trade plays a specific role in the synchronisation of business cycles. Also, the studies by Pentocete et al. (2011) contradict Krugman's thesis. The authors estimated equations that describe trade intensity, specialisation, financial links and new trade-related flows. The sample included 11 members of the euro area in the period 1995-2007. They noted that international trade intensity in these economies does not have any major impact upon production specialisation. However they add that production reveals some concentration tendencies, but, as they stress, that happens when countries are distant from each other, when their economies are relatively big, and under the assumption that the integration of their capital markets is low. It confirms the observations of Kalemli-Ozcan et al. (2001), according to which increased specialisation takes place when countries are divided only by a common border. In conclusion, we may state that an increase in trade or, more precisely, the increase in its intensity among the members of a common currency area importantly and positively influences the synchronisation of business cycles.

Artis et al. (2008) studied business cycle correlation in the years 1990-2004 among six members of the Eurozone and six new EU member states (the Czech Republic, Estonia, Hungary, Poland, Slovakia and Slovenia). The authors' thesis was that countries with a relatively high share of bilateral trade and financial flows (in this case FDI) have higher business cycle correlation coefficients. Initial analyses show that the group of the above mentioned six countries is relatively homogenous when it comes to the trade structure among the new member states which joined the EU in 2004. Nevertheless, the analyses revealed quite substantial differences in business cycles in the region. Business cycles in the Czech Republic, Estonia, and Slovakia differ from the cycles of other European Union 
member states. However, there was a relatively high correlation for Hungary, Poland and Slovenia in the period (on average 0.4 for growth cycles). Interestingly, in this last group of countries, the correlation is not much lower than the average correlation in bilateral relations between euro area members $(0.53$ for the growth cycle). Despite some heterogeneity of the studied countries, the analyses by Artis et al. show that for all these countries, business cycle synchronisation was assumed to be similar (low correlation was reported for Slovakia and Estonia: from 0.0 to 0.1). In the literature (Artis, Zhang, 1997) we can find the term "European business cycle", providing an additional argument for the hypothesis that economic integration results in highly correlated business cycles of the members of the grouping.

Artis's studies largely converge with what has been reported by other authors. Many of them, e.g. Darvas and Szapary (2005) as well as Fidrmuc and Korhonen (2006), conclude that business cycles of new EU member states (who joined on 1 May 2004) are close to the business cycles of the EU member states at the second half of the 1990s. At the beginning of the 1990s, business cycles were determined, in the authors' opinion, by the transitional transformation. For this reason, the correlation of business cycles remains low if measured at the beginning of the 1990s. Correlation between the cycles took place in the mid-1990s as a result of a dynamic increase in trade, especially in exports from candidate countries to the EU member states. The survey by Artis confirms the hypothesis of the endogeneity of the optimum currency area criterion. Enhanced trade intensity between countries, the inflow of FDI and intra-industry trade are indicative of business cycle synchronisation.

\section{Poland's international trade in the years 2000-2010 - an attempt at synthesis}

In the first decade of the 21st century, every year Poland reported high increases in exports to selected economies (Bilski, 2012). Exports to EU member states enjoyed the highest share. Within 10 years, exports to the EU had increased almost threefold in terms of its value in euro (ca. EUR 30 bn in 2000; EUR 90 bn in 2010). Exports to the euro area members, being a part of the above, also tripled (ca. EUR 20 bn in 2000; ca. EUR 60 bn in 2010). Analysis of exports and imports of Poland and of selected economies allows us to conclude that the dynamics of Polish exports between 2000-2008 is slightly higher compared to the euro area, speaking of intra-area, non-area and total trade. The year 2004, when Poland joined the EU, deserves special attention. The dynamics of exports to the then Eurozone countries increased by almost $27 \%$ compared to the previous year. It is remarkable that the global financial crisis which began in 2007 equally influenced the performance of Polish exports and the exports from the euro area, reaching in 2009 on average slightly more than $80 \%$ of the 2008 dynamics. The deepest 
drop in exports was reported for the Polish economy (almost 30 pp. in 2009 compared to 2008). When analysing trade turnover and its dynamics for selected economies in the years 2000-2010, we can conclude that trade turnover dynamics in the euro area did not diverge significantly from the dynamics of exports and imports of other EU member states. Thus, we might risk thestatement that Poland's trade depends on the economic situation of the countries with which the trade is the biggest.

Poland's exports dynamics (Figure 3) year-to-year was the highest in 2000 (133.9), and the lowest in 2009 (84.4), which reflected the crises which began in 2007, when the rate of increase in exports dropped from $20.7 \%$ in 2006 to $16.4 \%$ in $2007,19 \%$ in 2008 and $15.6 \%$ in 2009 , to increase by 35.6 pp. in 2010 . We should stress that when interpreting this data, one must remember that it was mainly due to low reference values of 2009 to which the data of 2010 is compared. It is interesting that in the years 2004-2005,the dynamics of exports to non-EU countries was clearly higher $(2004-138.1 ; 2005-129.5$; exports to EU: 124.5 and 116.6 respectively), by ca. $7 \mathrm{pp}$. in 2008 and by almost $10 \mathrm{pp}$. in 2009 compared to other groupings. The data in Figure 3 show that the downturn in the global economic situation at the end of 2008 hit all countries/groupings covered by the study. It greatly reduced the dynamics of exports from Poland both to non-EU countries (2009 - 77.6) and to the EU member states (2009 - 86.4).

Figure 3. Dynamics of Polish exports to selected economies in 2000-2010 in EUR bn (previous year $=100)$

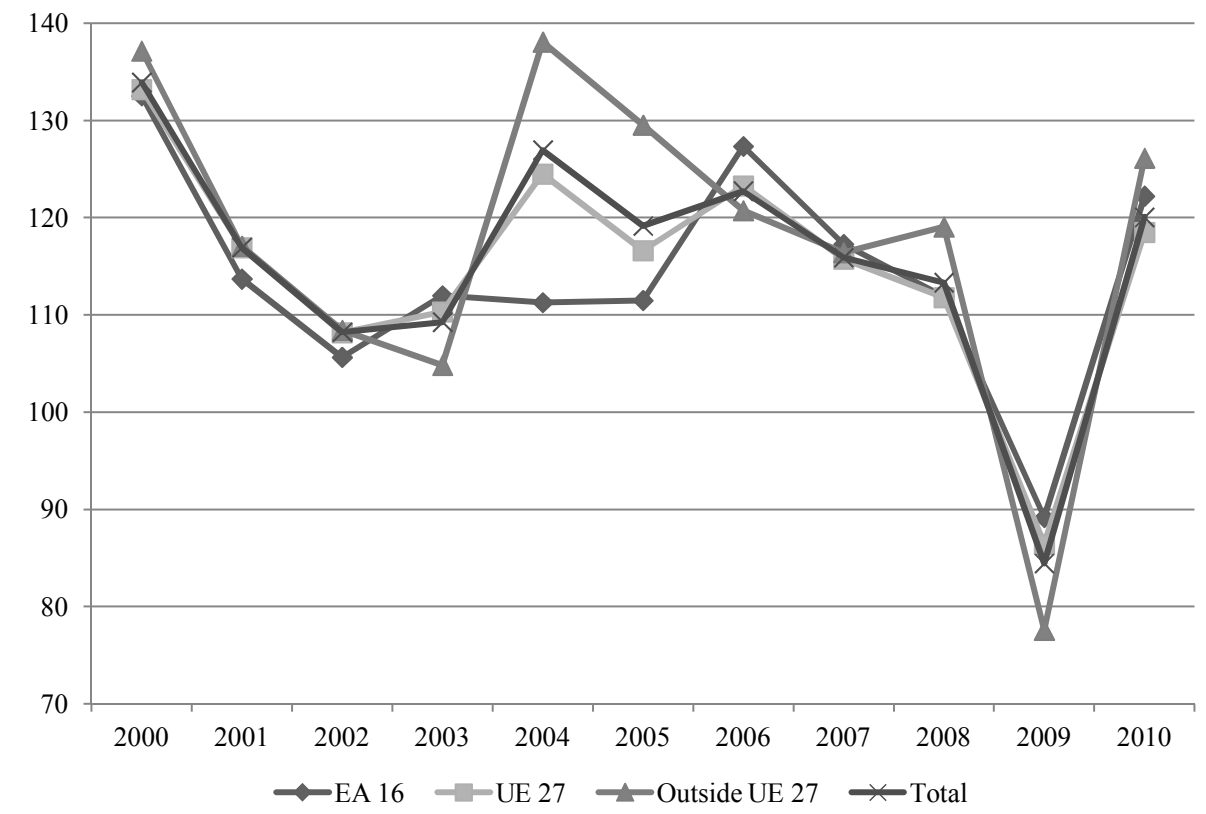

Source: own study based on the Eurostat and IMF data. 
While for Poland's exports in 2004 we can note that its dynamics, from period to period, were higher than the dynamics of Poland's exports to the EU member states, for imports to Poland the situation was the reverse (Figure 4). The increase of imports to Poland from the EU reached $29.3 \%$ in that period while from non-EU countries it was $-3 \%$. After the accession of Poland to the EU on 1 May 2004,imports from selected partners continued to recover until 2007 for the EU member states and until 2008 for the non-EU countries. 2007 marked the beginning of the financial crisis on global markets and the deep decline in the global economy.

Figure 4. Dynamics of imports to Poland from selected economies in 2000-2010 in EUR bn (previous year $=100$ )

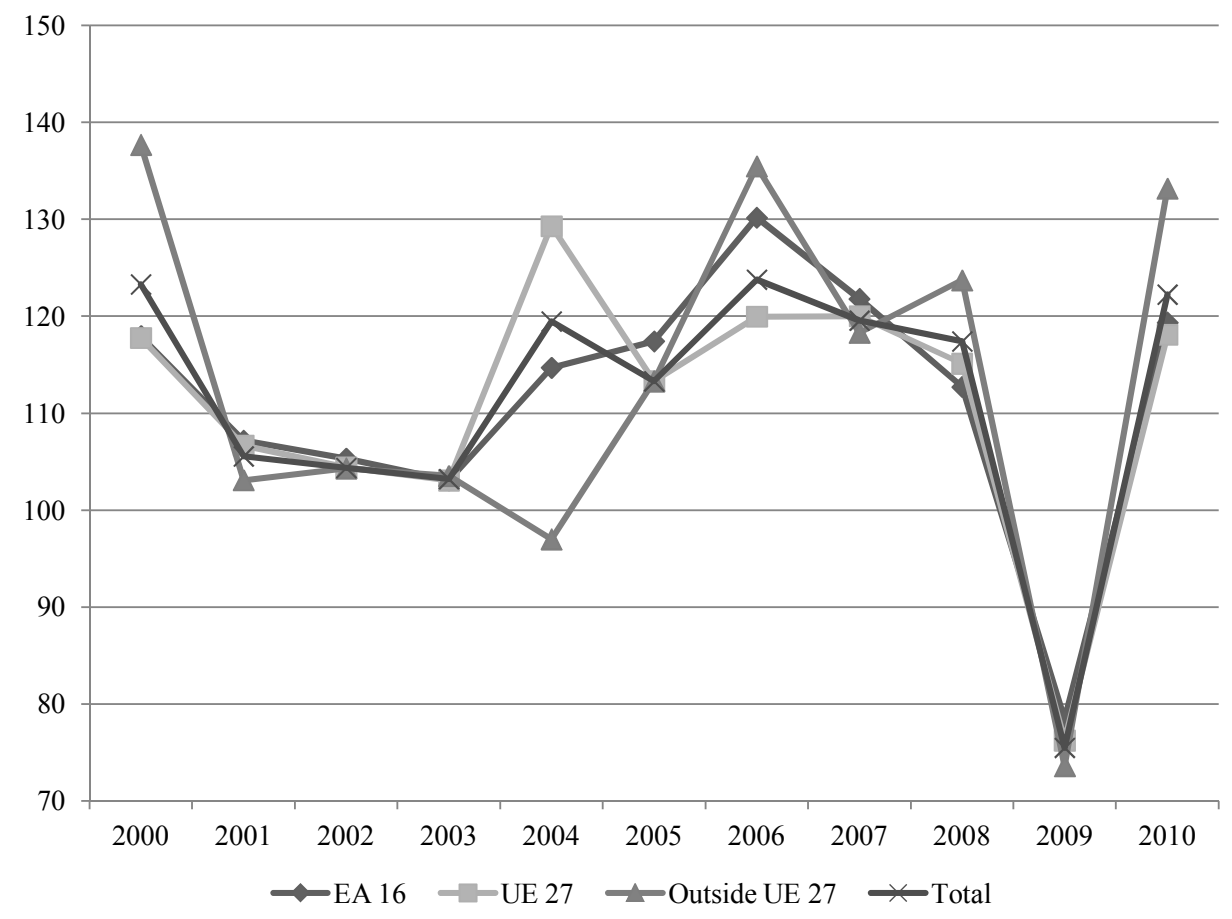

Source: own study based on the Eurostat and IMF data.

The data in Table 1 demonstrate that almost $80 \%$ of Polish exports and ca. $70 \%$ of imports are sold and bought in European Union member states, with the euro area countries accounting for ca. 55\% (2010) of the total exports of Poland and ca. 46\% (2010) of total imports. It means Polish trade dynamics areclosely linked with the economic situation and economic growth dynamics of the euro area countries and, more broadly, of the EU itself. 
Table 1. Structure of trade turnover with selected economies in 2000-2010 in EUR bn (\%)

\begin{tabular}{|l|l|l|l|l|l|l|l|l|l|l|l|l|l|l|l|}
\cline { 2 - 11 } \multicolumn{1}{|c|}{} & 2000 & 2001 & 2002 & 2003 & 2004 & 2005 & 2006 & 2007 & 2008 & 2009 & 2010 \\
\hline \multicolumn{8}{|c|}{ Share of Polish exports [\%] } \\
\hline $\begin{array}{l}\text { To euro } \\
\text { area in } \\
\text { total } \\
\text { exports }\end{array}$ & 60.0 & 58.3 & 56.9 & 58.3 & 51.1 & 47.9 & 49.6 & 50.2 & 49.6 & 52.4 & 53.3 \\
\hline $\begin{array}{l}\text { To euro } \\
\text { area in } \\
\text { exports } \\
\text { to EU-27 }\end{array}$ & 73.9 & 71.8 & 70.1 & 71.2 & 63.7 & 60.9 & 62.9 & 63.7 & 63.7 & 65.8 & 67.9 \\
\hline $\begin{array}{l}\text { Intra- } \\
\text {-EU27 }\end{array}$ & 81.2 & 81.2 & 81.2 & 81.9 & 80.3 & 78.6 & 79.0 & 78.9 & 77.8 & 79.6 & 78.6 \\
\hline \begin{tabular}{l} 
Non-EU \\
\hline
\end{tabular} & 18.8 & 18.8 & 18.8 & 18.1 & 19.7 & 21.4 & 21.0 & 21.1 & 22.2 & 20.4 & 21.4 \\
\hline $\begin{array}{l}\text { From } \\
\text { euro area } \\
\text { in total } \\
\text { imports }\end{array}$ & 56.9 & 57.8 & 58.3 & 58.3 & 55.9 & 58.0 & 61.0 & 62.1 & 59.6 & 62.0 & 60.5 \\
\hline $\begin{array}{l}\text { From euro } \\
\text { area in } \\
\text { imports } \\
\text { from } \\
\text { EU-27 }\end{array}$ & 82.6 & 83.0 & 83.7 & 83.7 & 74.3 & 77.0 & 83.5 & 84.8 & 83.0 & 85.4 & 86.3 \\
\hline $\begin{array}{l}\text { Intra- } \\
\text {-EU27 }\end{array}$ & 68.9 & 69.7 & 69.7 & 69.6 & 75.3 & 75.3 & 73.0 & 73.3 & 71.9 & 72.6 & 70.1 \\
\hline Non-EU & 31.1 & 30.3 & 30.3 & 30.4 & 24.7 & 24.7 & 27.0 & 26.7 & 28.1 & 27.4 & 29.9 \\
\hline
\end{tabular}

Source: own calculations based on Eurostat data.

Similarly to the members of the euro area and of the EU, periods of enhanced international trade were recorded in 2000 and between 2004-2008, while the trade decreased in 2009. We should highlight that, for Poland, the dynamics of exports and imports in 2000-2008 were higher, and on many ocassions much higher, than for other EU countries, with the exception of 2009, when the consequences of the financial and economic crisis were equally felt by all the EU economies, and 2010, the year of post-crisis economic activities. Analysis of the shares of individual countries in intra-Community trade (intra-EU27) lets us conclude that in the period 1999-2010 they did not change significantly. In 1999, the highest share in exports of the EU member states was enjoyed by Germany, France, the Netherlands, Great Britain, Italy, and Belgium. The overall exports of these countries amounted to $74.1 \%$. In 2010, their mutual exports were $68.4 \%$. For some countries, the share in intra-EU exports decreased (France: $13.1 \%$ in $1999,9.4 \%$ in 2010; Italy: $9.2 \%$ in 1999, $7.6 \%$ in 2010; Great Britain: $10.2 \%$ in $1999,6.5 \%$ in 2010). Although Poland's share of exports to other EU member states is relatively low, we should note its increase from $1.4 \%$ in 1999 to $3.6 \%$ in 2010 . 
Taking account of the data describing Polish trade in relation to the GDP in euro (Figure 5), we can say that intra-EU27 exports have a relatively high share in the GDP of Poland, mostly with the euro area members (exports to EU: $2001-15.4 \%, 2010$ $-26.1 \%$; including exports to the euro area: $2001-11 \%, 2010-17.7 \%)$. We must remember that in 2001 there were 15 member states in the European Union while in 2010 there are 27. Thus, within a decade we can observe an increase in trade turnover, which, to some extent, is a natural consequence of the higher number of parties involved.

Figure 5. Structure of Polish exports to selected economies in relation to GDP in 2001-2010 (\%)

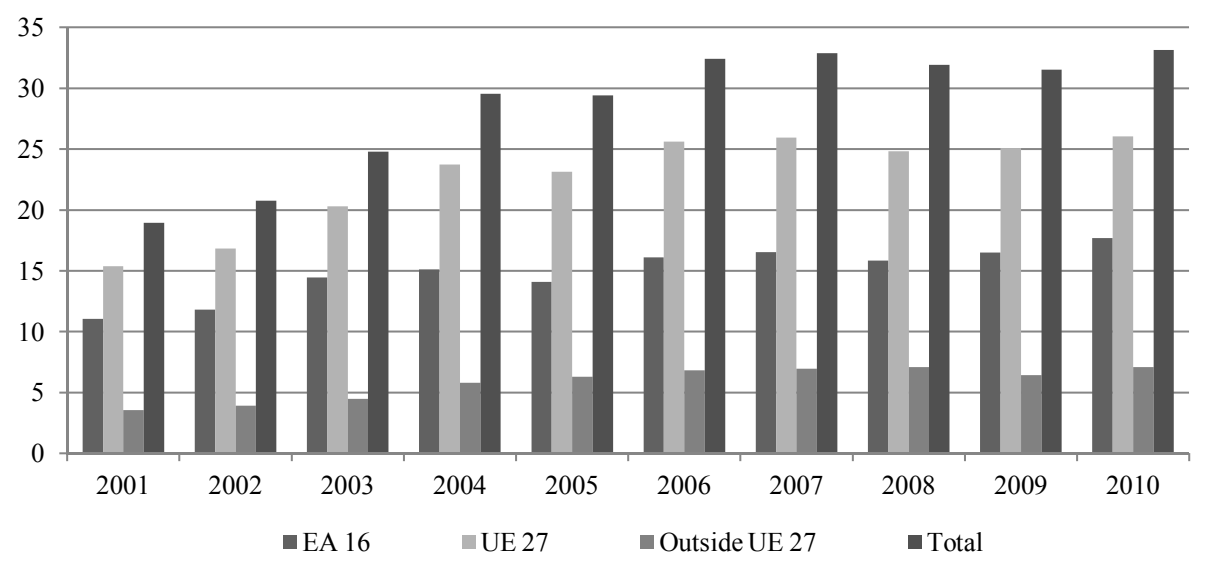

Source: own study based on Eurostat data.

Figure 6. Structure of imports to Poland from selected economies in relation to GDP in 2001-2010 (\%)

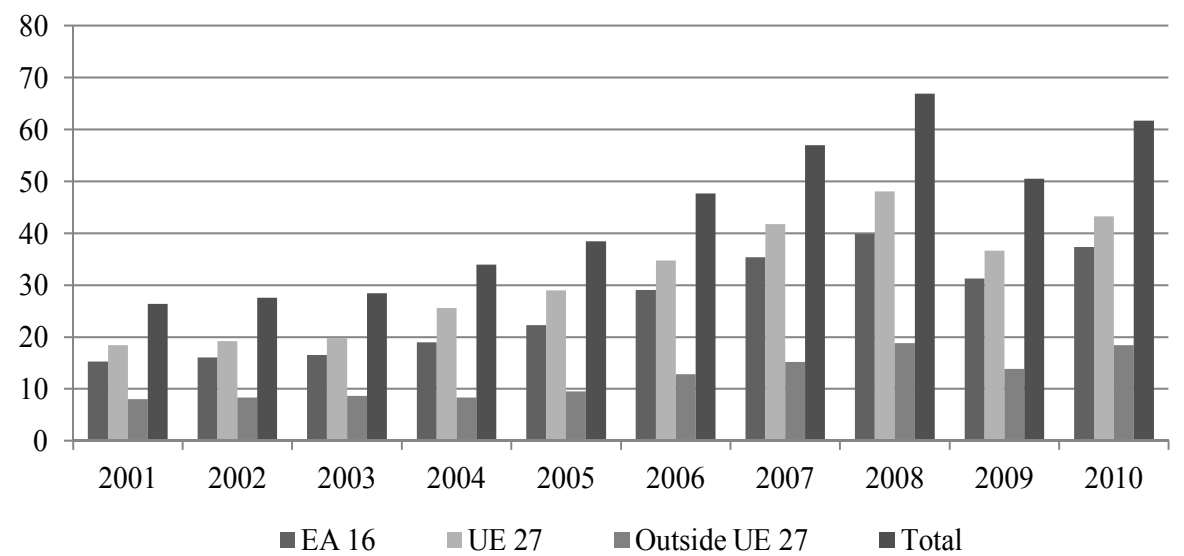

Source: own study based on Eurostat data.

It is worth paying special attention to the increasing importance of Polish exports to the euro area for the GDP. The total share of Poland's imports in the to- 
tal imports of the euro area members doubled since $2000(2 \%)$ and at present amounts to $4.1 \%$. When it comes to the importance of the Polish market for exports from the Eurozone countries, we are the market for 5.2\% (2010) of all the exports of the euro area (in 2000 the share was 3.1\%).

As in the case of exports, the increased share of imports in the GDP in EUR (Figure 6) can be largely explained by the increased number of countries involved in trade and taking part in various groupings. The share of imports from Poland in the GDP was $26.4 \%$ in 2001 , reaching $61.7 \%$ in 2010 . Surely most of the imports come from the EU member states (18.4\% in $2001 ; 43.3 \%$ in 2010), with the euro area members accounting for $15.3 \%$ in 2001 and $37.3 \%$ in 2010 .

Although the share of trade in the GDP continuously increased for Poland from the beginning of the 1990s (in particular with the EU member states), compared to other economies it is considered medium-high. It means exporters and importers are more interested in conducting a pass-through of the exchange rate fluctuations to domestic prices of traded products, as their profitability is largely determined by exchange rate fluctuations. For example, the share of Polish exporters in the GDP has increased since $2001(18.9 \%$ in 2001) to $31.5 \%$ in 2009 . For euro area members, it dropped from $37.3 \%$ in 2001 to $36.4 \%$ in 2009 (increases were recorded in $2007-41.8 \%$, and in $2008-42.1 \%$ ).

Table 2. Openness to trade in selected economies (\%)

\begin{tabular}{|l|c|c|c|c|c|c|c|c|c|}
\cline { 2 - 10 } \multicolumn{1}{c|}{} & 2001 & 2002 & 2003 & 2004 & 2005 & 2006 & 2007 & 2008 & 2009 \\
\hline Poland & 45.3 & 48.7 & 56.3 & 64.8 & 62.8 & 69.6 & 71.8 & 71.0 & 66.0 \\
\hline Extra-euro area & 29.5 & 28.4 & 27.3 & 28.6 & 30.6 & 32.9 & 33.5 & 34.6 & 28.4 \\
\hline EU & 19.4 & 18.4 & 17.8 & 18.7 & 20.2 & 21.5 & 21.6 & 23.0 & 19.6 \\
\hline $\begin{array}{l}\text { Euro area } \\
\text { (extra + intra) }\end{array}$ & 73.2 & 70.8 & 69.2 & 71.8 & 75.3 & 80.5 & 82.1 & 83.1 & 71.4 \\
\hline Intra-euro area & 43.7 & 42.4 & 41.9 & 43.2 & 44.8 & 47.6 & 48.6 & 48.5 & 43.0 \\
\hline
\end{tabular}

Source: own calculations based on Eurostat and IMF data.

The data let us conclude that Poland is a relatively open economy. In 2009, Polish exports and imports represented almost $66 \%$ of the GDP. Moreover, the trade is mostly directed to the euro area countries (ca. 53.3\%). Thus, in accordance with the results obtained by Rose (2008), if Poland acceded to the common currency area, and if its trade with the Eurozone increased by $1 \%$, the share of trade in the GDP would increase on average by $0.04 \%$ (in accordance with Rose's estimates: $0.1 \times 0.53 \times 0.66=0.04$ ).

Analysis of data in Figure 5 shows that the thesis on the relationship between foreign trade turnover and the size of the economy, known from the literature, has been confirmed in this case. It states that in a relatively small country, such as 
Poland, the share of exports in the GDP is higher than in bigger economies, e.g. the EU market (Maciejczyk-Bujnowicz, 2012). In territorial terms, the group of recipients of Polish goods is dominated by the European Union member states. The share of exports of Polish goods to the EU in the GDP accounted for 33.2\% in 2010 , and $26.1 \%$ of it ended up on the intra-EU27 market, including $17.7 \%$ in euro area members, and $7.1 \%$ was sold to non-EU countries.

In accordance with the traditional optimum currency area theory, economies in the currency union should have a similar although diversified structure of production, demand and exports, and a high intensity of trade relations (McKinnon 1963, Kenen 1969). In the member states of the euro area, similarly to the entire contemporary global economy, international specialisation and trade are based mainly on parallel exports and imports of goods of similar characteristics and high diversity (the so called intra-industry trade). In the case of Poland, intra-industry trade, in different goods of the same industry, is the most developed for machinery and equipment, means of transport, chemical products and finished consumer products (Misala, 2001). Intra-industry trade is of critical importance for the synchronisation of business cycles. In economies intertwined in this way, economic disturbances are symmetric. Empirical studies confirm a statistically significant dependence between the convergence of business cycles and the strength of intra-industry relations (Fidrmuc, 2001). At the beginning of the 1990s, the trade of Poland with the current members of the Eurozone followed the classic model of international trade based on comparative advantages (Cieślik, 2000). That was due to the fact that the Polish economy was complementary in relation to the euro area market, which was reflected in the indices of revealed comparative advantage, and highest for labourand raw materials-consuming goods. For technologically advanced goods, there was no competitive advantage. The relatively high share of low processed products (41.5\% in 1990; $13.2 \%$ in 2002) made Polish exports vulnerable to changes in the economic situation of the major trade partners and to exchange rate fluctuations. The structural transformations in the Polish economy, and most of all the inflow of FDI, increased the importance of more processed goods (mainly machinery and means of transport: $10.7 \%$ in $1990 ; 37.9 \%$ in 2002) (Report, 2009).

The share of intra-industry trade (i.e. simultaneous exports and imports within the same industry, of goods representing similar characteristics) in Poland was 0.7 in 2000, 0.8 in 2004, and 0.76 in 2008) (Misala, 2010). The intensity of this trade increased in Poland and is higher than in the euro area, where intra-industry trade decreased $(0.77 \text { in } 2000,0.73 \text { in } 2004 \text {, and } 0.70 \text { in 2008) })^{3}$. It means that exchange rate fluctuations, to a rather high degree, are passed through on import,

\footnotetext{
${ }^{3}$ According to Misala (2011): the most often used formula is the one proposed by Grubel and Lloyd (1975). In order to arrive at comparable data in various industries, intra-industry trade should be presented against the background of total international trade turnover in a given industry: $\mathrm{Ri}=(\mathrm{Xi}$ $+\mathrm{Mi})-|\mathrm{Xi}-\mathrm{Mi}| /(\mathrm{Xi}+\mathrm{Mi})$, where: $\mathrm{Ri}$ is intra-industry trade in industry $\mathrm{i},(\mathrm{Xi}+\mathrm{Mi})$ represents the global international turnover of the industry, i.e. the sum of exports and imports within a year, while $\mid \mathrm{Xi}$ $\mathrm{Mi}$ is the absolute value of the difference between the exports and imports of products of the industry.
} 
export, production and consumer prices. This is due to the fact that intra-industry trade in Poland is becoming more and more diversified and covers mainly products of low degree of substitution ${ }^{4}$ between domestic and foreign products, i.e. of a low degree of exchange rate fluctuation pass-through to prices. For Poland, the average share of basic products and raw materials accounted for ca. $25 \%$ in exports and ca. 40\% in imports between 1992-2006. It means highly processed goods had the highest share in exports and imports in the analysed period. For the Eurozone, the average share of basic products and raw materials in total exports was ca. $30 \%$ while in exports it did not exceed $50 \%$. Thus, the comparison of the data shows that both in the euro area and in Poland, the share of intra-industry trade in international trade is relatively similar, which, according to the above presented thesis on business cycle synchronisation, means it reduces the risk of asymmetric shocks.

The above considerations relating to trade are just one of many elements taken into account by countries facing the decision on joining the currency union. Cost and benefit analysis includes many other factors, which, when analysed together, produce opposite results. For example, Maliszewska (2004) analysed bilateral trade flows between EU member states and countries of Central and Eastern Europe in the years 1992-2007 (857 observations) using the OLS method. It means that when Poland adopts the euro, trade will increase on average by $23 \%$, while for EU countries treated in total as an integration grouping, the value was negative. Cieślik et al. (2008) analysed the trade consequences of Poland's accession to the Economic and Monetary Union using the generalised gravity model. In the opinion of the authors of the study, Polish exports immediately after joining the euro area will increase by ca. $12 \%$. In the study, the authors took account of the specificity of the Polish economy and of other Central and Eastern European countries, which, unlike the present members of the euro area, are less developed and have a different structure of exports and imports. The authors' analyses show that the effect of trade expansion may emerge just after the decision to join the euro area and obligation to stabilise the exchange rate. Further, they maintain that joining the euro area should contribute to further increases in the trade (exports) of Poland with other countries in the area. They claim the expansion effect may be reduced in the longer term. On top of that, the euro area stimulates imports from third countries but it is limited to exportation. The authors interpret these results as an effect of internal and external trade expansion.

Interesting studies on the synchronisation of the Polish economy with the euro area countries were conducted by Adamowicz et al. (2009) within a research project in the National Bank of Poland in 2009. The most important conclusions from their studies and analyses are presented in points. Some of them are worth our attention. Firstly, as shown by the analysis, the structure of the Polish econo-

\footnotetext{
${ }^{4}$ Transmission of exchange rate fluctuations is relatively high for less processed goods, with a high degree of replace ability, and relatively low for more processed goods with a low degree of replace ability.
} 
my compared to the structures of the economies of the euro area shows considerable differences. They relate mainly to the structure of production, employment and income. The Polish economy represents a higher share of sectors of low value added: mining and extraction industries as well as agriculture and a lower share of services. (...) Relatively smaller differences were detected in the demand structure. Poland has a higher share of goods with low prices and income elasticity of demand, however, the demand structure reveals some similarities to the euro area, in particular to its the biggest countries. In the authors' opinion, the above differences may be potential sources of asymmetric macroeconomic shocks. Secondly, strong cyclical output fluctuations of the economy were found. In the period covered by the study, 4 short cycles were distinguished, of between 2.5 to 4 years, with upward phases slightly longer than downward ones. Differences in the length of the cycle and its phases appeared depending on the method of time series filtration and on how the cycle was measured. The studies showed a significant similarity of the business cycle in the euro countries and in Poland. The biggest revealed differences concerned the Russian crisis and the accession boom felt more in Poland than in the euro area countries. Output fluctuations in Poland occur earlier there than in the euro countries. Fourthly, from among all the analysed quantitative variables, the closest synchronisation for business cycles in Poland and in the euro countries was found for industrial production sold, investment, and GDP; identified fluctuations have common turning points but the intensity of individual phases differs. High synchronisation of the GDP cycles and industrial production sold, with simultaneous lower synchronisation of the consumption cycle for Poland, was confirmed by e.g. Darvas and Szapary (2004). The biggest coherence of cyclical fluctuations was reported between Poland and the average for 12 euro area countries. Among individual countries, the biggest similarities in cyclical fluctuations were detected between the Polish and German economies. When it comes to differences in fluctuations of variables between Poland and the euro area, the closest similarities were revealed between Poland and smaller EU countries: Spain, Portugal, and Ireland. In general terms, the results of the study give grounds to conclude that there is synchronisation of business cycle fluctuations in Poland and in the euro area. The conclusion concurs, in general, with conclusions from most similar analyses. The results of the studies by Konopczak (2009) confirm the thesis that the Polish economy, compared to other countries in the region, and to euro area members, shows a high degree of synchronisation with the cycle of the area as a whole. The author finds disturbing theinsignificant correlation of structural shocks hitting Poland and euro area countries. She adds that the absence of autonomous instruments of shock accommodation, such as the exchange rate and monetary policy at national level, may be the cost of Poland's membership in the euro area. In conclusion, the author states that with the coherence of some shocks after joining the currency union, one may expect cyclical convergence, and that for Poland the optimum currency area criteria will be endogenous. 


\section{Summary}

The literature review shows that one of the benefits of joining the euro area is trade recovery and intensification. Trade recovery is supported by the elimination of costs of transaction and of the risk of exchange rate fluctuations. Taking account of the share of Polish exports and imports in the GDP, despite their continuous increases since the beginning of the 1990s, trade is still considered medium high compared to other economies. Poland's trade with the current members of the euro area was consistent with the classic model of international trade based on comparative advantages, which resulted from the complementarity of the Polish economy vis-à-vis the euro area. Since 2000, both in the euro area and in Poland, the share of intra-industry trade in exports and imports is relatively close, meaning it reduces the risk of asymmetric shocks. It is estimated that if Poland adopts the euro, trade will increase on average by $23 \%$ (Maliszewska 2004). According to estimates (Rose, 2008), when Poland joins the common currency area, if trade with the euro area increased by $8 \%$, the share of trade in the GDP would increase by almost 3\%. According to Cieślik et al. (2008) exports from Poland, directly after joining the euro area, will increase by ca. 12\%. Konopczak (2009) verifies the validity of the thesis that the Polish economy, compared to other countries in the region and to euro area members, reveals a high degree of synchronisation with the cycle of the area. The author adds that the absence of autonomous instruments of the accommodation of shocks, such as the exchange rate and national monetary policy, may be the cost of joining the euro area for Poland. On the basis of the above considerations, we may conclude that joining the monetary union will initiate a cyclical convergence for Poland while optimum currency area criteria for Poland will be endogenous.

\section{References}

Adamowicz E., Dudek S., Pachucki D., Walczyk K. (2009), Synchronizacja cyklu koniunkturalnego polskiej gospodarki z krajami strefy euro w kontekście struktury tych gospodarek, Raport na temat pełnego uczestnictwa Rzeczypospolitej Polskiej w trzecim etapie Unii Gospodarczej i Walutowej, NBP, Warsaw 2009.

Artis M.J., Fidrmuc J., Scharler J. (2008), The transmission of business cycles. Implications for EMU enlargement, Economics of Transition, Vol. 16(3), p. 559-582.

Artis M.J., Zhang W. (1997), International business cycles and the ERM: Is there a European Business cycle?, International Journal of Finance and Economics, Vol. 2, p. 1099-1158.

Babetskii I. (2005), Trade integration and synchronization of shocks: Implications for EU enlargement,Economics of Transition, No. 13, p. 105-138. 
Baldwin R. (2006), The Euro's Trade Effects, ECB Working Paper, No. 594.

Bilski J. (2012), Wpływ kursu walutowego na handel zagraniczny, PWE, Warsaw. Bilski J. (2006), Międzynarodowy system walutowy, PWE, Warsaw.

Bussiere M., Fidrmuc J., Schnatz B. (2008), EU enlargement and trade integration:

Lessons from gravity model, Review of Development Economics, Vol. 12(3), p. $562-576$.

Cieślik A. (2000), Nowa teoria handlu zagranicznego w świetle badań empirycznych, PWN, Warszawa.

Cieślik A., Michałek J., Mycielski J. (2009), Analiza skutków handlowych przystąpienia Polski do Europejskiej Unii Monetarnej przy użyciu uogólnionego modelu grawitacyjnego, NBP [in:] Raport na temat pełnego uczestnictwa Rzeczypospolitej Polskiej w trzecim etapie Unii Gospodarczej i Walutowej.

Darvas Z., Szapary G. (2005), Business cycle synchronisation In the enlarged EU: Comovements in the New and old members, Discussion Paper No. 5179, London, CEPR.

De Grauwe P. (2003), Unia Walutowa, PWE, Warszawa.

De Grauwe P., Schnabl G. (2004), Exchange Rate Regime and Macroeconomic Stability in Central and Eastern Europe, CESIfo Working Paper No. 1182.

EC Commission (1990), One market, One money, European Economy, No. 44.

Fidrmuc J. (2001), The Endogenity of the Optimum Currency Area Criteria, Intraindustry Tradeand EMU Enlargement, BOFIT Discussion Paper, No. 8.

Fidrmuc J., Korhonen I. (2006), Meta-analysis of the business cycle correlation between the euro area and the CEECs', Journal of Comparative Economics, No. 34, p. 518-537.

Flandreau M., Maurel M. (2005), Monetary union, trade integration, and business cycles in 19th century Europe, Open Economies Review, 16, p. 135-152.

Frankel J., Rose A.(2002), An Estimate of the Effect of Common Currencies on Trade and Income, Quarterly Journal of Economics 117, p. 437-466.

Frankel J., Rose A.K. (1997), Is EMU More Justifiable Ex Post than Ex Ante?, The European Economic Review.

Frankel J., Rose A.K. (1998), The Endogeneity of the Optimum Currency Area Criteria, Economic Journal.

Frankel J.A. (2004), Real convergence and euro adoption in Central and Eastern Europe: Trade and business cycle correlations as endogenous criteria for joining EMU, Working Paper No. 04-039, J.F. Kennedy School of Government, Harvard University.

Kalemli-Ozcan S., Sorensen B.E., Yosha O. (2001), Economic integration, industrial specialization, and the asymmetry of macroeconomic fluctuations, Journal of International Economics, No. 55, 107-137.

Kenen P. (1969), The Theory of Optimum Currency Areas: An Eclectic View [in:] Mundell R., Swoboda, (eds), Monetary Problems in the International Economy, University of Chicago Press. 
Konopczak K. (2009), Analiza zbieżności cyklu koniunkturalnego gospodarki polskiej ze strefą euro na tle krajów Europy Środkowo-Wschodniej oraz państw członkowskich strefy euro, Raport na temat pełnego uczestnictwa Rzeczypospolitej Polskiej w trzecim etapie Unii Gospodarczej i Walutowej, NBP, Warsaw.

Krugman P. (1993), Lessons of Massachusetts for EMU [in:] Torres F., Giavazzi F. (eds), Adjustment and Growth in the European Monetary Union, CEPR, London, CUP, Cambridge.

Lutkowski K. (2004), Od złotego do euro, TWIGGER, Warsaw.

Lutkowski K. (2009), Raport nt. uczestnictwa Rzeczypospolitej Polskiej w trzecim etapie Unii Gospodarczej Walutowej, NBP.

Maciejczyk-Bujnowicz I. (2012), Uwarunkowania wymiany handlowej Polski w latach 2000-2010 - wybrane zagadnienia [in:] Bilski J. (ed.), (2012), Wpływ kursu walutowego na handel zagraniczny, PWE, Warszawa, p. 57-121.

Maliszewska M.A. (2004), New Member States Trading Potential Following EMU accession: A Gravity Approach, Studies and Analysis, No. 286, CASE - Centre for Social and Economic Research.

McKinnon R. (1963), Optimum Currency Areas, American Economic Review, September.

Micco A., Stein E., Ordonez G. (2003), The Currency Union Effect on Trade: Early Evidence from EMU,Economic Policy 37, p. 315-356.

Misala J. (2010), Zmiany kursu walutowego i dynamika cen w krajach o różnym poziomie rozwoju gospodarczego, Oficyna Wydawnicza SGH, Warsaw.

Misala J. (2011), Międzynarodowa konkurencyjność gospodarki narodowej, PWE, Warsaw, p. 167 and further.

Misala J. (2001),Współczesne teorie wymiany międzynarodowej i zagranicznej polityki ekonomicznej, Szkoła Główna Handlowa, Warszawa.

Mongelli F. (2002), New Views on the Optimum Currency Area Theory - What is EMU Telling Us?, ECB Working Paper, No 138, ECB, Frankfurt am Main.

Mundell R. (1961), A Theory of Optimum Currency Areas, The American Economic Review, Vol. 51, No. 4, s. 657-665.

Pentocete J.S., Poutineau J.C., Rondeau F. (2011), Trade, Extensive Margin on Trade and Business Cycle Synchronization in the case of EMU, CREM CNRS 6211, University of Rennes 1, February 2011.

Raport na temat korzyści i kosztów przystąpienia Polski do strefy euro, NBP, Warsaw 2004.

Rose A.K. (2008), EMU, trade and business cycle synchronization: What do we know and what does it mean for Poland?, Raport nt. pełnego uczestnictwa Rzeczypospolitej Polskiej w trzecim etapie Unii Gospodarczej Walutowej, eseje zagranicznych i polskich ekonomistów, NBP.

Tchorek G. (2009), Raport nt. uczestnictwa Rzeczypospolitej Polskiej w trzecim etapie Unii Gospodarczej Walutowej, NBP.

Wójcik C. (2008), Integracja ze strefą euro, PWN, Warsaw. 


\section{Summary}

The paper focuses on one of the aspects of the OCA theory and on a new endogenous approach analysing mutual trade links of the countries in a common currency area. According to Kinnon (1963), a high degree of openness of the candidate countries is a precondition for establishing an OCA. Thus, the area can be created by countries with a high share of exports and imports in their GDP. The more open an economy, the higher the importance of the exchange rate for prices. We reviewed the literature on selected studies on the subject and analysed statistical data describing Poland's trade in the years 2000-2010 with the euro area and EU member states outside of it.

Keywords: Optimal Currency Area Theory, export, import, Poland, European Union, currency exchange rate

\section{Streszczenie}

Handel wymienny a teoria optymalnych obszarów walutowych. Implikacje dla Polski

Artykuł koncentruje się na jednym z aspektów TOOW oraz nowego endogenicznego podejścia, którym jest analiza wzajemnych powiązań handlowych krajów wspólnego obszaru walutowego. Według McKinnona (1963) podstawowym kryterium tworzenia OOW jest wysoki stopień otwarcia gospodarek państw kandydujących. A zatem obszar ten mogą tworzyć kraje o dużym udziale handlu zagranicznego w produkcie narodowym. Im bardziej otwarta gospodarka, tym większe znaczenie w kształtowaniu cen w kraju ma kurs walutowy. Dokonano analizy literaturowej wybranych badań w badanym przedmiocie oraz analizy danych statystycznych odnoszących się do wymiany handlowej Polski w okresie 2000-2010 pomiędzy strefą euro oraz krajami należącymi do Unii Europejskiej pozostającymi poza unią walutową.

Slowa kluczowe: Teoria Optymalnego Obszaru Walutowego, eksport, import, Polska, Unia Europejska, kurs walutowy

JEL: F14, F15, F31

This paper was financed under the research grant of the National Science Centre No.: UMO-2013/09/B/HS4/01329 "Impact of Capital Imports upon Economic Growth". 